\title{
IMPACT OF SOIL CONDITIONERS AND WEATHER ON LAWN COMPACTNESS
}

\author{
JANKOWSKI, K. ${ }^{*}$ - SOSNOWSKI, J. - TRUBA, M. - SKRZYCZYŃSKA, J. - \\ MALINOWSKA, E. - WIŚNIEWSKA-KADŻAJAN, B. \\ Department of Grassland and Green Areas Creation \\ Siedlce University of Natural Sciences and Humanities \\ Prusa 14 Street, 08-110 Siedlce, Poland \\ *Coresponding author \\ e-mail: kazimierz.jankowski@uph.edu.pl \\ (Received $13^{\text {th }}$ Jul 2017; accepted $5^{\text {th }}$ Oct 2017)
}

\begin{abstract}
The aim of this paper is to determine the effect of soil conditioners and one mineral fertilizer on turf, as well as their interaction with meteorological conditions in maintaining of lawn compactness. The field experiment was conducted in the experimental facility between 2013 and 2015. The following grass species were used in the experiment: Lolium perenne, Festuca rubra, and Poa pratensis. Another experimental factor tested in the research was soil conditioners. Between 2013 and 2015 an assessment of grass compactness based on the methods described by Domański (1998) was carried out. This assessment was conducted in three seasons: spring, summer, and autumn. Grass species tested in the experiment formed turf of different compactness, varying throughout seasons of the year and responding strongly to weather conditions. In drier periods red fescue had better turf, contrary to smooth meadow grass and perennial ryegrass, both of which had better turf in more humid conditions. Out of all the types of fertilizer Humus Active Papka affected turf compactness in the most favourable way although the response of individual grass species was not the same. From a practical point of view out of the grass species tested in the experiment Poa pratensis treated with Eko-Użyźniacz responded the most favourably.
\end{abstract}

Keywords: compactness, turf quality, red fescue, smooth meadow, grass perennial ryegrass

\section{Introduction}

Architects dealing with spatial planning pay more and more attention to green areas, with lawns, relatively inexpensive to set up, being their important element. Lawns have multiple functions, from environmental, through sanitary-hygienic, to recreational and aesthetic (Czeluściński et al., 2017).

The increase in the standard of living in Poland and other countries is accompanied by the awareness of the importance of green areas and the need for an attractive and healthy environment (Watsson et al., 1992). Lawns are common in parks, gardens, streets, squares, and recreational areas (Ignatieva et al., 2015; Bertoncini et al., 2012; Stewart at al., 2009). Dense and uniform turf is the most important element of lawn functional value (Domański 1998; Grabowski et al., 1999; Harkot and Czarnecki, 2001; Harkot et al., 2006; Jankowski et al., 2010, 2011a; Prończuk et al., 1997). According to Jankowski et al. (2011d, 2012a) as well as Rutkowska and Pawluśkiewicz (1996) turf quality largely depends on its treatment and maintenance, on habitat conditions, but also on the proper selection of grass species and varieties used to set up a lawn (Wheeler et al., 2017).

Grass is commonly used for lawns, regardless of their type. Some 160 grass species can be found in Poland (Prończuk and Żurek, 2008). Yet, with such a huge number only 16 species are suitable for lawns. Festuca rubra (red fescue), Poa pratensis (smooth 
meadow grass), and Lolium perenne (perennial ryegrass) are grass species most common on lawns used extensively (Jankowski et al., 2012b).

To a large extent lawn quality depends on frequent watering, which in turn affects maintenance costs (Jankowski et al., 2011a; Jankowski et al., 2011b; Jankowski et al., 2011c; Jankowski et al., 2011d; Jankowski et al., 2011e). The use of modern watering systems is not always a good solution. Usually those systems are too expensive and not every owner can afford such an investment (Jankowski et al., 2012a).

With the growing interest in the use of environmentally friendly products, numerous soil conditioners have been approved for the use in green areas, fulfilling the role of fertilizer, or chemicals used in plant protection. Continuous progress in the studies on soil conditioners shows their competitiveness in relation to conventional solutions.

The aim of this paper is to determine the effect of soil conditioners and one mineral fertilizer on turf, as well as their interaction with meteorological conditions in maintaining of lawn compactness. The study deals with practical aspects of the impact of soil conditioners on the compactness value of individual species of lawn grass. In addition, the research aims at getting information about the extent to which soil conditioners can replace mineral fertilizer without degrading functional value of the lawn.

\section{Material and methods}

Set up in 2012 the field experiment was conducted in the experimental facility of the University of Natural Sciences and Humanities in Siedlce $\left(52^{\circ} 12^{\prime} \mathrm{N}, 22^{\circ} 28^{\prime} \mathrm{E}\right)$ between 2013 and 2015. The research was carried out as a mini-plot experiment, in the split plot design with three replications and the plot area of $1 \mathrm{~m}^{2}$. The following grass species were used in the experiment (factor B): Lolium perenne -variety Info, Festuca rubra variety Nil, and Poa pratensis -variety Alicja. They were sown on their own, each of them at the rate of $28 \mathrm{~g} / \mathrm{m}^{2}$. Another experimental factor tested in the research was soil conditioners (factor A)

Soil conditioners used in the experiment improve soil properties, according to the Institute of Soil Science and Plant Cultivation (IUNG) in Puławy. The composition of the soil conditioners used in the research is presented in Table 1.

The UGmax soil conditioner is an extract from compost, containing macronutrients $(\mathrm{N}, \mathrm{P}, \mathrm{K}, \mathrm{Mg}, \mathrm{Na})$ and micronutrients $(\mathrm{Mn})$. It also contains lactic acid bacteria, photosynthetic bacteria, Azotobacter, Pseudomonas, yeast, and Actinomycetes. The micro-organisms in the conditioner have a capacity of processing organic and natural fertilizers into compost and humus. These processes are conducive not only to the production of humus but also to improving soil structure, which in turn has a positive effect on water balance in the soil. In addition, the UGmax soil conditioner increases disease resistance, keeping plants healthy, but it also stimulates the development of the root system and supports the biological reduction of molecular nitrogen.

Humus Active Papka contains macronutrients (N, P, K, Ca, Mg), trace elements (Mn, $\mathrm{Fe}, \mathrm{Zn}, \mathrm{Cu}$ ), and active humus with useful microorganisms. According to the manufacturer Humus Active, among other beneficial effects, positively affects plant health as well as soil structure, and releases nutrients not readily available to plants. 
Table 1. Composition of soil conditioners applied in the experiment.

\begin{tabular}{|c|c|c|c|c|c|c|c|c|c|c|c|c|}
\hline \multirow{2}{*}{$\begin{array}{c}\text { Soil } \\
\text { conditioner }\end{array}$} & \multicolumn{6}{|c|}{$\begin{array}{l}\text { Macronutrients } \\
\left(\mathrm{g} \cdot \mathrm{kg}^{-1}\right)\end{array}$} & \multicolumn{5}{|c|}{$\begin{array}{c}\text { Micronutrients } \\
\left(\mathrm{mg} \cdot \mathrm{kg}^{-1}\right)\end{array}$} & \multirow{2}{*}{$\begin{array}{l}\text { Microorganism } \\
\text { and others }\end{array}$} \\
\hline & $\mathbf{N}$ & $\mathbf{P}$ & $\mathbf{K}$ & $\mathrm{Ca}$ & Mg & $\mathbf{N a}$ & Mn & $\mathbf{F e}$ & $\mathrm{Zn}$ & $\mathrm{Cu}$ & Mo & \\
\hline $\begin{array}{l}\text { Substral } \\
\text { (S) }\end{array}$ & 220 & 21.8 & 83 & & 12.06 & & 12 & 50 & 12.5 & 12.5 & 1 & - \\
\hline $\begin{array}{l}\text { Humus } \\
\text { Astive } \\
\text { Papka } \\
\text { (HAP) }\end{array}$ & 0.2 & 1.3 & 4.6 & 3.0 & 0.5 & - & 15 & 500 & 3 & 1 & - & $\begin{array}{l}\text { Active humus } \\
\text { with useful } \\
\text { microorganisms }\end{array}$ \\
\hline $\begin{array}{c}\text { Eko- } \\
\text { Użyźniacz } \\
\text { (EU) }\end{array}$ & 0.6 & 0.3 & 0.7 & - & - & - & - & - & - & - & - & $\begin{array}{l}\text { Endo } \\
\text { micorhizza, } \\
\text { fungi, bacteria, } \\
\text { enzymes of } \\
\text { earthworms }\end{array}$ \\
\hline $\begin{array}{l}\text { UGmax } \\
\text { (UG) }\end{array}$ & 1.2 & 0.2 & 2.9 & - & 0.1 & 0.2 & 0.3 & - & - & - & - & $\begin{array}{l}\text { lactic acid } \\
\text { bacteria, } \\
\text { photosynthetic } \\
\text { bacteria, } \\
\text { Azotobacter, } \\
\text { Pseudomonas, } \\
\text { yeast, } \\
\text { Actinomycetes }\end{array}$ \\
\hline
\end{tabular}

Eko-Użyźniacz is extracted from bovine vermicompost and contains the main macronutrients $(\mathrm{N}, \mathrm{P}, \mathrm{K})$, micro-organisms, and enzymes related to metabolism of earthworms. This soil conditioner stimulates biological life in soil degraded chemically, mechanically, or biologically, and increases plant resistance to different stress factors.

Soil conditioners were applied annually in spring (mid May) in the following doses: UGmax $-25 \mathrm{ml} \cdot \mathrm{m}^{-2}\left(0.61\right.$ in 2501 of water), Eko-Użyźniacz $-100 \mathrm{ml} \cdot \mathrm{m}^{-2}(101 \mathrm{in}$ 1001 of water), and Humus Active Papka $-250 \mathrm{ml} \cdot \mathrm{m}^{-2}$ ( 0.21 for 101 of water). In turn, Substral, a slow release fertilizer used on lawns, was used in the quantity of $20 \mathrm{~g} \cdot \mathrm{m}^{-2}$.

At the end of each growing season between 2013 and 2015 an assessment of grass based on the methods described by Domański (1998) was carried out. Among other things its compactness was assessed in accordance with the methodology by Prończuk and Żurek (2008), using a 9-point rating scale in which 1 stands for no aesthetic value; 3 for unattractive appearance; 5 for average; 7 for attractive; 9 for very attractive. This assessment was conducted in three seasons: spring, summer, and autumn. In each year of the research spring assessment was made around May 20, summer assessment around 20 August, and autumn assessment around October 10.

The experiment was set up on the soil developed from loamy sand, belonging to anthropogenic soils of the culture-earth order, and of the type of hortisole (Systematics of Polish Soils). Chemical analysis showed that the soil was alkaline, with high content of magnesium and phosphorus, and low potassium content. The test results were evaluated statistically with the analysis of variance. Tukey's test $(\mathrm{P} \leq 0.5)$ was used to find significantly different means of the effects of experimental factors and their 
interaction. Based on lawn appearance ratings, standard deviation and coefficient of variation were calculated for separate seasons, years, and soil conditioners.

\section{Weather conditions}

Meteorological data between 2013 and 2015 were obtained from the Hydrological and Meteorological Station in Siedlce. The average air temperature during the experiment was very similar to the long-term average temperature (Table 2). In each year of the research the highest temperature was in July (19.3 on average) and August (19.0), while the lowest temperature, taking into account only the growing season, was in April (an average of 8.5) and October (an average of 8.2).

Table 2. Average air temperature $\left({ }^{\circ} \mathrm{C}\right)$ and precipitation $(\mathrm{mm})$ in individual months of the growing seasons.

\begin{tabular}{c|ccccc|cc|c}
\hline \multirow{2}{*}{ Year } & \multicolumn{7}{c}{ Month } \\
\cline { 2 - 9 } & Apr. & May & June & July & Aug. & Sept. & Oct. & Means \\
\hline \multicolumn{7}{c}{ Temperature $\left({ }^{\circ} \mathbf{C}\right)$} \\
2013 & 7.5 & 15.3 & 17.7 & 18.8 & 18.3 & 11.4 & 9.6 & 14.1 \\
2014 & 9.7 & 13.7 & 15.1 & 20.5 & 17.8 & 13.7 & 8.4 & 14.1 \\
2015 & 8.2 & 12.3 & 16.5 & 18.7 & 21.0 & 14.5 & 6.5 & 14.0 \\
Means & 8.5 & 13.8 & 16.4 & 19.3 & 19.0 & 13.2 & 8.2 & 14.1 \\
Long-term means & 8.5 & 14.0 & 17.4 & 19.8 & 18.9 & 13.2 & 7.9 & 14.2 \\
\hline \multicolumn{7}{|c|}{ Rainfall (mm) } \\
\hline 2013 & 57.6 & 145.8 & 111.9 & 49.1 & 44.1 & 86.6 & 18.0 & 73.3 \\
2014 & 39.5 & 79.5 & 74.2 & 37.5 & 105.7 & 26.3 & 3.0 & 52.2 \\
2015 & 30.0 & 100.2 & 43.3 & 62.6 & 11.9 & 77.1 & 39.0 & 52.0 \\
Means & 42.4 & 108.5 & 76.5 & 49.7 & 53.9 & 63.3 & 20.0 & 59.2 \\
Long-term means & 33.0 & 52.0 & 52.0 & 65.0 & 56.0 & 48.0 & 28.0 & 47.7 \\
\hline
\end{tabular}

A meteorological element with major temporal fluctuations is rainfall (Skowera and Puła, 2004). By analyzing its amount in different months of the experiment it was found that the lowest average monthly precipitation was in $2015(52.0 \mathrm{~mm})$, but still it was higher by $2.3 \mathrm{~mm}$ than the long-term average. In the growing season of 2013 the average monthly precipitation of $73.3 \mathrm{~mm}$ was the highest. May 2013 was a month in which rainfall was the highest of all months during the experiment $(145.8 \mathrm{~mm})$. The lowest rainfall was recorded in October $2014(3.0 \mathrm{~mm})$ and August $2015(11.9 \mathrm{~mm})$.

In order to determine the temporal variation of meteorological elements and their effects on vegetation, Sielianinov's hydrothermal coefficient (Bac et al., 1993) was calculated on the basis of monthly rainfall $(\mathrm{P})$ and the monthly total air temperature $(\Sigma \mathrm{t})$, using the formula: $\mathrm{K}=\mathrm{P} / 0.1 \Sigma \mathrm{t}$ (Skowera and Puła, 2004).

In assessing temperature and moisture conditions ten-scale classification of Sielianinov's hydrothermal coefficient $(\mathrm{K})$ was used, which, according to Skowera and Puła (2004), has the following ranges:

$$
\begin{aligned}
\mathrm{K} & \leq 0.4 \text { extremely dry (ss); } \\
0.4<\mathrm{K} & \leq 0.7 \text { very dry (bs); } \\
0.7 & <\mathrm{K} \leq 1.0 \text { dry (s); }
\end{aligned}
$$


$1.0<\mathrm{K} \leq 1.3$ quite dry (ds);

$1.3<\mathrm{K} \leq 1.6$ optimal (o);

$1.6<\mathrm{K} \leq 2.0$ quite wet $(\mathrm{dw})$;

$2.0<\mathrm{K} \leq 2.5$ wet (in);

$2.5<\mathrm{K} \leq 3.0$ very wet (bw);

$\mathrm{K}>3.0$ extremely wet (sw).

The values of Sielianinov's hydrothermal coefficient for individual months of the experiment are shown in Table 3. It was assumed that the conditions were extreme when coefficient values were below 0.7 and above 2.5 (Skowera and Puła, 2004).

Table 3. Sielianinov's hydrothermal coefficient $(K)$ during the growing season.

\begin{tabular}{c|c|c|c|c|c|c|c}
\hline \multirow{2}{*}{ Years } & \multicolumn{7}{|c}{ Month } \\
\cline { 2 - 8 } & Apr. & May & June & July & Aug. & Sept. & Oct. \\
\hline 2013 & $2.56(\mathrm{bw})$ & $3.07(\mathrm{sw})$ & $2.11(\mathrm{w})$ & $0.84(\mathrm{~s})$ & $0.78(\mathrm{~s})$ & $2.53(\mathrm{bw})$ & $0.60(\mathrm{bs})$ \\
2014 & $1.36(\mathrm{o})$ & $1.87(\mathrm{dw})$ & $1.64(\mathrm{dw})$ & $0.59(\mathrm{bs})$ & $1.92(\mathrm{dw})$ & $0.64(\mathrm{bs})$ & $0.12(\mathrm{ss})$ \\
2015 & $1.22(\mathrm{ds})$ & $2.63(\mathrm{bw})$ & $0.87(\mathrm{~s})$ & $1.08(\mathrm{ds})$ & $0.18(\mathrm{ss})$ & $1.46(\mathrm{o})$ & $1.94(\mathrm{dw})$ \\
\hline
\end{tabular}

Optimal temperature and moisture conditions were only in April 2014 and in September 2015. In the remaining months of all the growing seasons the weather conditions were not as favourable, varying from extremely dry in August 2015 to extremely wet in May 2013. Throughout the experiment the best conditions occurred at the beginning of each growing season. It can be concluded that the most difficult period for plants was in 2015, when, apart from May and the end of the growing season, the weather conditions ranged from quite dry to extremely dry.

\section{Results and discussion}

According to different authors (Prończuk et al., 1997; Harkot and Czarnecki, 2001; Jankowski et al., 2011a), dense and uniform turf has a big impact on the functional value of a lawn. Lawn appearance is one of the most important features determining its compactness. Rutkowska and Pawluśkiewicz (1996) point out that turf compactness is influenced by many factors, such as environmental conditions, the kind and frequency of maintenance treatment, the appropriate selection of grass species and varieties, and the way in which the lawn is used.

Table 4. Assessment of turf compactness (9-point scale) in the spring from 2013 to 2015.

\begin{tabular}{c|c|c|c|c|c|c}
\hline \multirow{2}{*}{$\begin{array}{c}\text { Year } \\
(\mathbf{C})\end{array}$} & $\begin{array}{c}\text { Species } \\
(\mathbf{B})\end{array}$ & \multicolumn{4}{|c|}{ Fertilizers (A) } & \multirow{2}{*}{$\bar{x}$} \\
\cline { 3 - 6 } 2013 & Smooth meadow grass & 8.8 & $(\mathbf{S U})$ & $\mathbf{( H A P )}$ & $(\mathbf{U G )}$ & 8.8 \\
& Perennial ryegrass & 7 & 6.9 & 7.8 & 6.6 & 7.1 \\
& Red fescue & 8.7 & 8.9 & 9 & 9 & 8.9 \\
& Smooth meadow grass & 8.9 & 8 & 8.1 & 8.6 & 8.4 \\
2014 & Perennial ryegrass & 8.7 & 8.3 & 7.6 & 8.9 & 8.4 \\
& Red fescue & 8.3 & 6.2 & 5.9 & 8.8 & 7.3 \\
& Smooth meadow grass & 7.8 & 8.3 & 8.1 & 8.1 & 8.1
\end{tabular}




\begin{tabular}{c|c|c|c|c|c} 
Perennial ryegrass & 9 & 8.7 & 8.9 & 7.9 & 8.6 \\
Red fescue & 8.7 & 8.9 & 9 & 9 & 8.9 \\
\hline & \multicolumn{5}{|c}{ Species effect - means } \\
\hline Smooth meadow grass & 8.5 & 8.4 & 8.4 & 8.4 & 8.4 \\
Perennial ryegrass & 8.2 & 8 & 8.1 & 7.8 & 8 \\
Red fescue & 8.6 & 8 & 8 & 8.9 & 8.4 \\
\hline \multirow{6}{*}{ Fertilizer effect - means } \\
\cline { 2 - 6 } & 8.4 & 8.1 & 8.4 & 8.4 & 8.3 \\
\cline { 2 - 6 } & \multicolumn{6}{|c|}{ Average annual assessment } \\
\hline 2013 & 8.2 & 8.3 & 8.6 & 8.1 & 8.3 \\
2014 & 8.6 & 7.5 & 7.2 & 8.8 & 8 \\
2015 & 8.5 & 8.6 & 8.7 & 8.3 & 8.5 \\
\hline
\end{tabular}

$\mathrm{LSD}_{0.05}: \mathrm{A}=\mathrm{NS} ; \mathrm{B}=\mathrm{NS} ; \mathrm{C}=\mathrm{NS} ; \mathrm{A} / \mathrm{B}=\mathrm{NS} ; \mathrm{B} / \mathrm{A}=\mathrm{NS} ; \mathrm{A} / \mathrm{C}=1.04 ; \mathrm{C} / \mathrm{A}=0.93 ; \mathrm{B} / \mathrm{C}=0.81 . ; \mathrm{C} / \mathrm{B}=0.81$.

Turfs of the lawns studied in this experiment were diverse both in terms of the species tested and the fertilizer applied. Their compactness changed throughout years and seasons of research. Assessment of the lawn turfs showed that their quality in the spring (Table 4) varied throughout the experiment, and it was different for different species of grass. In the spring of the first and third year red fescue had the best turf $\left(8.9^{\circ}\right)$ in comparison with the other species. In turn, in the second year (2014) the compactness of this grass was the worst of all of them $\left(7.3^{\circ}\right)$. These differences were statistically significant.

Changes in the compactness of red fescue turf were related to the weather. Red fescue is one of those species that reach optimum development in habitats with variable water conditions and often even in dry places. Therefore, in 2013 and 2015, in which years there were a lot of dry periods (Tables 2 and 3), this grass formed a good quality turf. Similarly, in the studies of Grabowski et al. (1999) and Jankowski et al. (2011c) seeding mixtures with a high proportion of red fescue formed the best turf. According to Golińska (2002) high turf-forming potential of red fescue is a specific and important feature.

Throughout the research in the spring seasons (Table 4) both smooth meadow grass and red fescue had the best turf, both at the level of $8.4^{\circ}$, as the average of three years between 2013 and 2015. According to Martyniak and Prończuk (2003), chewings fescue has rhizomes of varying length underground, and they form very strong and dense turf. Therefore, it is an excellent grass with good compactness turf on grassland, lawns, and other areas. Additionally, comparing different species with different types of fertilizer applied, it was found that the best turf in the spring was on the plot with red fescue treated with UGmax $\left(8.9^{\circ}\right)$. The worst lawn $\left(7.8^{\circ}\right)$ was on the plot with perennial ryegrass, also treated with UGmax. In the case of smooth meadow grass lawn compactness did not vary much (from 8.4 to $8.5^{\circ}$ ), no matter what type of fertilizer was used. In the studies of Kitczak et al. (2000) smooth meadow grass had a better turf than a mixture with perennial ryegrass.

Assessing the effect of fertilisers in the spring it was found that for all of the grass species turf compactness was similar, no matter whether Substral, Humus Active Papka, or UGmax was applied, being at the same level of $8.4^{\circ}$. Eko-Użyźniacz was an exception causing slightly weaker lawn compactness $\left(8.1^{\circ}\right)$

Assessing the effect of different forms of fertilizer in different spring seasons, turf of the best compactness was in the spring of 2015 (from 8.3 to $8.7^{\circ}$ ). That year the best 
grass was on the plots with Humus Active Papka $\left(8.7^{\circ}\right)$ and Eko-Użyźniacz $\left(8.6^{\circ}\right)$. Similarly, in 2013 these forms of fertilizer ensured the best lawns (8.6 and $8.3^{\circ}$, respectively). In 2014, which was the wettest year (Tables 2 and 3), turf on plots treated with Humus Active Papka and Eko-Użyźniacz was the worst $\left(7.2\right.$ and $7.5^{\circ}$, respectively), but it was best of all as a result of UGmax $\left(8.8^{\circ}\right)$ and Substral $\left(8.6^{\circ}\right)$ application. Statistical analysis showed a significant interaction between the year of the research and the form of fertilizer in their impacts on turf compactness.

Table 5. Assessment of turf compactness (9-point scale) in the summer from 2013 to 2015.

\begin{tabular}{|c|c|c|c|c|c|c|}
\hline \multirow{2}{*}{$\begin{array}{l}\text { Year } \\
\text { (C) }\end{array}$} & \multirow{2}{*}{$\begin{array}{c}\text { Species } \\
\text { (B) }\end{array}$} & \multicolumn{4}{|c|}{ Fertilizers (A) } & \multirow{2}{*}{$\bar{x}$} \\
\hline & & (S) & $(\mathbf{E U})$ & (HAP) & (UG) & \\
\hline \multirow{3}{*}{2013} & Smooth meadow grass & 8.8 & 7.9 & 9 & 9 & 8.7 \\
\hline & Perennial ryegrass & 8.9 & 7.6 & 7.5 & 9 & 8.3 \\
\hline & Red fescue & 3.3 & 7.9 & 8.4 & 3.8 & 5.9 \\
\hline \multirow{3}{*}{2014} & Smooth meadow grass & 9 & 9 & 8.9 & 8.8 & 8.9 \\
\hline & Perennial ryegrass & 8.7 & 9 & 8.8 & 8.9 & 8.9 \\
\hline & Red fescue & 9 & 8.8 & 8.9 & 8.9 & 8.9 \\
\hline \multirow{3}{*}{2015} & Smooth meadow grass & 5.9 & 8.2 & 6.1 & 7.3 & 6.9 \\
\hline & Perennial ryegrass & 9 & 5.6 & 8.4 & 7.8 & 7.7 \\
\hline & Red fescue & 2.8 & 4.2 & 3.1 & 3.9 & 3.5 \\
\hline & & \multicolumn{4}{|c|}{ Species effect - means } & \\
\hline \multirow{3}{*}{\multicolumn{2}{|c|}{$\begin{array}{l}\text { Smooth meadow grass } \\
\text { Perennial ryegrass } \\
\text { Red fescue }\end{array}$}} & 7.9 & 8.4 & 8 & 8.4 & 8.2 \\
\hline & & 8.9 & 7.4 & 8.2 & 8.5 & 8.3 \\
\hline & & 5 & 7 & 6.8 & 5.5 & 6.1 \\
\hline & & \multicolumn{4}{|c|}{ Fertilizer effect - means } & \\
\hline & & 7.3 & 7.6 & 7.7 & 7.5 & 7.5 \\
\hline & & \multicolumn{4}{|c|}{ Average annual assessment } & \\
\hline & 2013 & 7 & 7.8 & 8.3 & 7.3 & 7.6 \\
\hline & 2014 & 8.9 & 8.9 & 8.9 & 8.9 & 8.9 \\
\hline & 2015 & 5.9 & 6 & 5.9 & 6.3 & 6 \\
\hline
\end{tabular}

$\mathrm{LSD}_{0.05}: \mathrm{A}=\mathrm{NS} ; \mathrm{B}=1.44 . ; \mathrm{C}=1.44 ; \mathrm{A} / \mathrm{B}=\mathrm{NS} ; \mathrm{B} / \mathrm{A}=\mathrm{NS} ; \mathrm{A} / \mathrm{C}=\mathrm{NS} ; \mathrm{C} / \mathrm{A}=\mathrm{NS} ; \mathrm{B} / \mathrm{C}=2.25 ; \mathrm{C} / \mathrm{B}=2.25$.

In the summer (Table 5) turf compactness was slightly worse than in the spring time, and to a greater extent it was dependent on weather conditions (Tables 2 and 3). The best possible degree of turf compactness for each species of grasses was in 2014 (on average $8.9^{\circ}$ for each species). The spring that year was rainy (Table 3), with hydrothermal coefficient indicating optimal conditions in April, but quite wet in May and June. Similarly, during the summer that year weather conditions were much more favourable for grass than in the other two years of the research. For all the grass species the highest average compactness rating $\left(8.9^{\circ}\right)$ was also in 2014 , when, on average, lawns treated with different types of fertilizer had the same turf compactness. Comparing all the species throughout the experiment, in summer seasons perennial ryegrass formed the best lawn (on average $8.3^{\circ}$ ), and with references to the forms of fertilizer, Substral was the most effective $\left(8.9^{\circ}\right)$. Red fescue had the worst lawn in summer (an average of $6.1^{\circ}$ ), and with regard to fertilizer types, plots with Substral $\left(5^{\circ}\right)$ and UGmax $\left(5.5^{\circ}\right)$ had turf of the lowest compactness. Statistical analysis revealed significant differences in the degree of turf compactness between red fescue and the other two species of grasses. The interaction between the form of fertilizer and grass 
species in their effect on the turf compactness turned out to be statistically significant. Comparing the effect of the forms of fertilizer on all grass species during summer in all experimental years, the application of Humus Active Papka $\left(7.7^{\circ}\right)$ resulted in the best turf, while the effect of Substral $\left(7.3^{\circ}\right)$ was the worst. Differences between the impacts of both of them were not statistically significant.

Table 6. Assessment of turf compactness (using 9-point scale) in the autumn from 2013 to 2015.

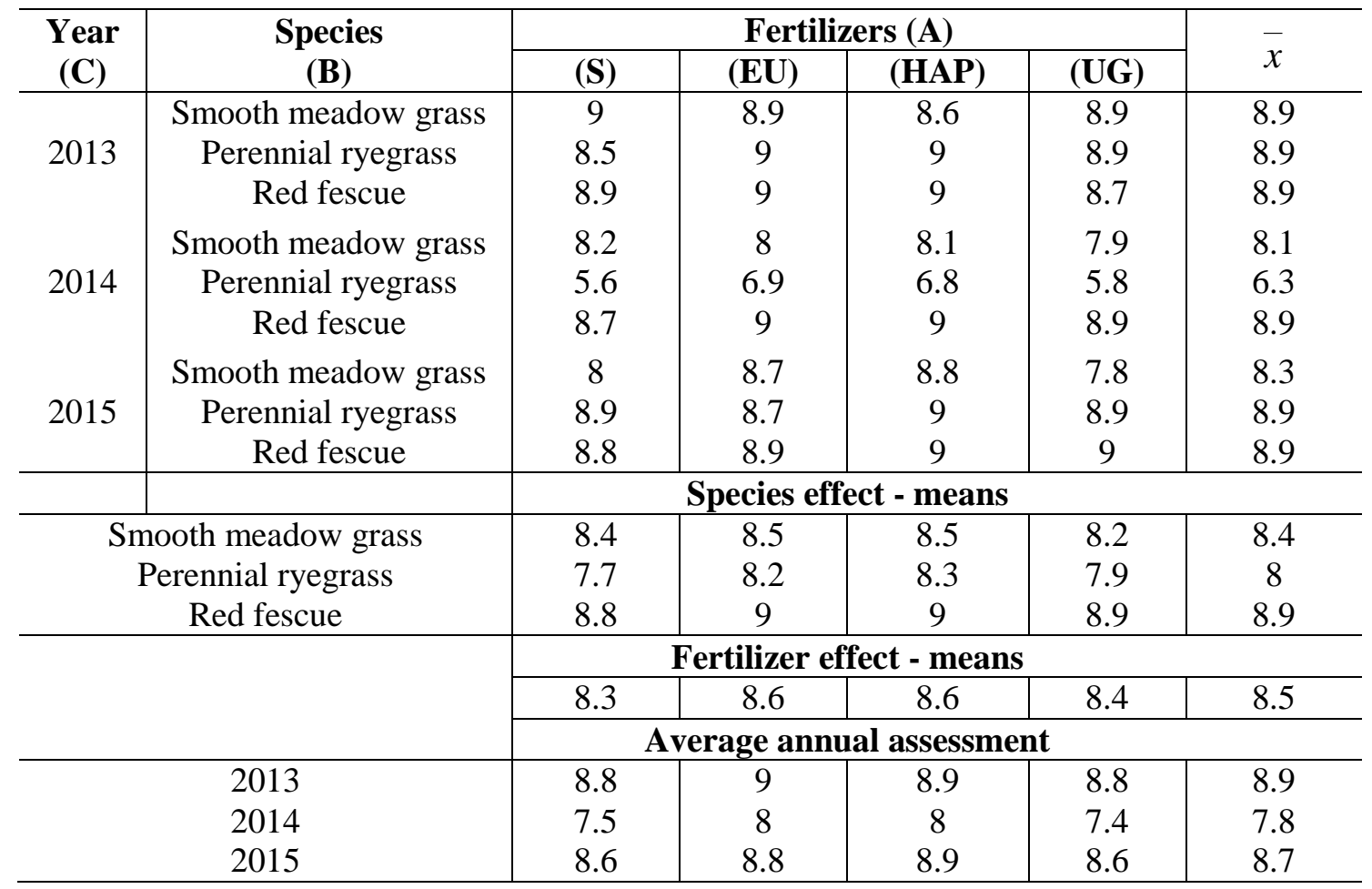

$\mathrm{LSD}_{0.05} \mathrm{~A}=\mathrm{NS} ; \mathrm{B}=0.67 ; \mathrm{C}=0.67 ; \mathrm{A} / \mathrm{B}=\mathrm{NS} ; \mathrm{B} / \mathrm{A}=\mathrm{NS} ; \mathrm{A} / \mathrm{C}=\mathrm{NS} ; \mathrm{C} / \mathrm{A}=\mathrm{NS} ; \mathrm{B} / \mathrm{C}=0.64 ; \mathrm{C} / \mathrm{B}=0.64$.

The turfs in autumn seasons (Table 6) were to a large extent a reflection of meteorological conditions (Tables 2 and 3). During this period the most adverse weather conditions for grass development were in 2014 (Table 3), when September was very dry and October extremely dry. In effect, turf compactness was the worst (an average of $7.8^{\circ}$ ) although red fescue that year was in good condition (on average $8.9^{\circ}$ ), while much worse lawns were those with perennial ryegrass (on average $6.3^{\circ}$ ). Those differences were statistically significant. In the other two years (2013 and 2015), when water conditions were by far better, turf was at its best (from 8 to $9^{\circ}$ ). The experiment showed significant differences in turf compactness between grass species and between autumn seasons. As an average for all grass species, the best turf was in 2013 and 2015. In addition, the best turf was obtained as a result of the application of Eko-Użyźniacz (9.0 in 2013 and $8.8^{\circ}$ in 2015) and Humus Active Papka (8.9 ${ }^{\circ}$ in both years). In autumn seasons red fescue had the best turf (from 8.8 to $9.0^{\circ}$ ), and with regard to the type of fertilizer, in the same seasons both Eko-Użyźniacz (9 in 2013 and 8.8 in 2015) and Humus Active Papka ( $8.9^{\circ}$ in 2013 and 2015) application resulted in a very good lawn.

Out of the grass species in the autumn perennial ryegrass had the worst turf (on average $8.0^{\circ}$ ). Statistical analysis showed that the interaction between the grass species 
and the year of research in their effect on lawn compactness was statistically significant. In assessing the effects of fertilizer types on all grass species in each year, it was found that in the autumn Eko-Użyźniacz and Humus Active Papka increased turf compactness in autumn seasons the most $\left(8.6^{\circ}\right)$.

Table 7. Fertilizer effect on turf compactness (9-point scale). Means within species, years, and season.

\begin{tabular}{|c|c|c|c|c|c|}
\hline \multirow{2}{*}{$\begin{array}{l}\text { Species } \\
\text { (B) }\end{array}$} & \multicolumn{4}{|c|}{ Fertilizers (A) } & \multirow{2}{*}{$\bar{x}$} \\
\hline & (S) & $(\mathbf{E U})$ & (HAP) & (UG) & \\
\hline Smooth meadow grass & 8.3 & 8.4 & 8.3 & 8.3 & 8.3 \\
\hline Perennial ryegrass & 8.3 & 7.9 & 8.2 & 8.1 & 8.1 \\
\hline Red fescue & 7.5 & 8 & 7.9 & 7.8 & 7.8 \\
\hline \multicolumn{6}{|c|}{ Fertilizer effect - means } \\
\hline & 8 & 8.1 & 8.2 & 8.1 & 8.1 \\
\hline \multicolumn{6}{|c|}{ Average annual assessment } \\
\hline 2013 & 8 & 8.4 & 8.6 & 8.1 & 8.3 \\
\hline 2014 & 8.3 & 8.1 & 8 & 8.4 & 8.2 \\
\hline 2015 & 7.7 & 7.8 & 7.8 & 7.7 & 7.7 \\
\hline \multicolumn{6}{|c|}{ Average assessment in seasons (D) } \\
\hline spring & 8.4 & 8.1 & 8.4 & 8.4 & 8.3 \\
\hline summer & 7.3 & 7.6 & 7.7 & 7.5 & 7.5 \\
\hline autumn & 8.3 & 8.6 & 8.6 & 8.4 & 8.5 \\
\hline
\end{tabular}

$\mathrm{LSD}_{0.05}: \mathrm{A}=\mathrm{NS} ; \mathrm{B}=0.41 ; \mathrm{C}=0.49 ; \mathrm{D}=0.33$

By comparing average grass species ratings in the experiment as a whole (Table 7) it turned out that smooth meadow grass had the best turf $\left(8.3^{\circ}\right)$ and red fescue the worst $\left(7.8^{\circ}\right)$. Differences in the degree of turf compactness between grass species were statistically significant, especially between smooth meadow grass and red fescue. Grabowski et al. (1999) pointed out that the advantage of smooth meadow grass is its durability and high turf-making potential. In Poland in this regard this species easily competes with perennial ryegrass. Out of the types of fertilizer Humus Active Papka application resulted in the best turf $\left(8.2^{\circ}\right)$ in the experiment, although differences in its compactness on plots with different forms of fertilizer were small and not statistically significant. With regard to the seasons it was found that generally the best turf was in the autumn $\left(8.5^{\circ}\right)$ and spring $\left(8.3^{\circ}\right)$ and the worst in the summer $\left(7.5^{\circ}\right)$. Differences in the degree of its compactness between the summer, the spring, and the autumn were not statistically significant. Whatever the time of the year, in subsequent years of research the average assessment rating systematically deteriorated from $8.3^{\circ}$ in 2013 to $7.7^{\circ}$ in 2015, and these differences were statistically significant.

Table 8. Standard deviation and coefficient of variation in assessing of turf compactness

\begin{tabular}{c|c|c|c|c|c}
\hline Species & $\begin{array}{c}\text { Min. } \\
\text { rating }\end{array}$ & $\begin{array}{c}\text { Max. } \\
\text { rating }\end{array}$ & $\begin{array}{c}\text { Means } \\
\text { values }\end{array}$ & $\begin{array}{c}\text { Standard } \\
\text { deviation }\end{array}$ & $\begin{array}{c}\text { Coefficient of } \\
\text { variation }\end{array}$ \\
\hline Smooth meadow grass & 5.9 & 9 & 8.33 & 0.737 & 8.84 \\
Perennial ryegrass & 5.6 & 9 & 8.10 & 1.052 & 12.98 \\
Red fescue & 2.8 & 9 & 2.06 & 2.062 & 26.48 \\
\hline
\end{tabular}

Coefficient of variation: 0-20\% - small variability, 20 - 40\% - medium variability, 40-60\% - large variability, > 60\% - very large variability 
By analyzing the durability of compactness ratings in relation to particular grass species (Table 8) it turned out that coefficient of variation for smooth meadow grass and perennial ryegrass was the most favourable, indicating moderate variability. For red fescue the coefficient of variation of compactness rating was above $20 \%$, indicating medium variability. Therefore, to install a lawn, smooth meadow grass both on its own and in mixtures, should be recommended first of all.

\section{Conclusions}

1. Grass species tested in the experiment formed turf of different compactness, varying throughout seasons of the year and responding strongly to weather conditions. In drier periods red fescue had better turf, contrary to smooth meadow grass and perennial ryegrass, both of which had better turf in more humid conditions.

2. Out of all the types of fertilizer Humus Active Papka affected turf compactness in the most favourable way although the response of individual grass species was not the same.

3. Out of all the grass species smooth meadow grass and red fescue had the best turf on plots where Humus Active Papka was applied, and perennial ryegrass had the best turf on plots with Substral. In the subsequent years of research there was a deterioration of lawn compactness, with a weakening effect of all types of fertilizer, in particular in the case of Eko-Użyźniacz and Humus Active Papka.

4. From a practical point of view out of the grass species tested in the experiment Poa pratensis treated with Eko-Użyźniacz responded the most favourably.

\section{REFERENCES}

[1] Bac, S., Koźmiński, C., Rojek, M. (1993): Agrometeorology. - PWN, Warszawa, 32-33.

[2] Bertoncini, A. P., Machon, N., Pavoine, S., Muratet, A. (2012): Local gardening practices shape urban lawn floristic communities. - Landscape and Urban Planning 105: 53-61.

[3] Czeluściński, W., Jankowski, K., Sosnowski, J., Malinowska, E., Wiśniewska-Kadżajan, B. (2017): Effects of trinexapac-ethyl on turfgrass growth and frequency of mowing. Applied Ecology and Environmental Research 15(3): 739-746.

[4] Domański, P. (1998): Methodology of economic value analysis of cultivated plant varieties. Turf grasses: red fescue, tymothy, meadow grass, ryegrass. - COBORU, Słupia Wielka: s. 35. (In Polish).

[5] Grabowski, K., Grzegorczyk, S., Benedycki, S., Kwietniewski, H. (1999): The evaluation of the usage value of the chosen species and varieties of the gazon grasses for the swing of the grass surfaces. - Fol. Univ. Agric. Stein. 197, Agricultura 75: 81-88. (In Polish).

[6] Golińska, B. (2002): Evaluation of suitability of selected cultivars of Festuca rubra and Festuca ovina for extensive use of the lawn. - Scientific Review of the Faculty of Environmental Engineering and Environment, SGGW, 1(24): 123-128.

[7] Harkot, W., Czarnecki, Z. (2001): Variability of the general aspect of Polish lawn grass varieties on mineral soil with mechanically damaged upper layer. - Acta Agrophisica 51: 71-76. (In Polish) 
[8] Harkot, W., Czarnecki, Z., Powroźnik, M., Rosołowski, G. (2006): Influence of mowing frequency on general aspect of turf of selected Festuca ssp. cultivars during seven-years performance. - Grassland Science in Poland 9: 59-65. (In Polish)

[9] Ignatieva, M., Ahrné, K., Wissman, J., Eriksson, T., Tidåker, P., Hedblom, M., Kätterer, T., Marstorp, H., Berg, P., Eriksson, T., Bengtsson, J. (2015): Lawn as a cultural and ecological phenomenon: A conceptual framework for transdisciplinary research. - Urban For. Urban Green 14: 383-387.

[10] Jankowski, K., Czeluściński, W., Jankowska, J., Ciepiela, G.A. (2010): Effect of aquagel on the initial development of turfgrasses and their aesthetical value. - J. Res. Appl. Agric. Eng. 55(2): 36-41. (In Polish).

[11] Jankowski, K., Czeluściński, W, Jankowska, J. (2011a): Effect of hydrogel and type of fertilizer on the turf compactness with varying participation of perennial ryegrass in mixture. - Folia Pom. Univ. Techn. Stetinesis. Agric. 286 (18): 13-22. (In Polish).

[12] Jankowski, K., Czeluściński, W., Jankowska, J., Sosnowski, J. (2011b): The effect of hydrogel and different fertilisers on the regrowth rate of lawns composed of perennial ryegrass. - Journal of Water and Land Development T.11, 2 (34): 73-82. (In Polish).

[13] Jankowski, K., Sosnowski, J., Jankowska, J. (2011c): Effect of hydrogel and different types of fertilizers on the numer of turf shoots in lawns created by monocultures of red fescue (Festuca rubra L.) Cultivars and its mixtures. - Acta Agrobotanica 64(3):109-118.

[14] Jankowski, K., Sosnowski, J., Szczykutowicz, A. (2011d): Grading of grassland grasslands based on red fescue using hydrogels in the substrate. - News of Melioration and Meadow 2: 89-92. (In Polish).

[15] Jankowski, K., Tkaczuk, C., Jankowska, J., Czelusciński, W. (2011e): Estimation of over wintering and degree of infestation with snow mold of lawn grasses depend on fertilization and hydrogel. - Fragm. Agron. 28(2): 26-34. (In Polish).

[16] Jankowski, K., Sosnowski, J., Jankowska, J., Kowalczyk, R. (2012a): Imapct of hydrogel and kind of soil cover on the compactness of turf lawns. - Ecological Engineering 30: 249-256. (In Polsh).

[17] Jankowski, K., Czeluściński, W., Jankowska, J., Kolczarek, R., Sosnowski, J. (2012b): The influence of the growth regulator trinexsapac ethyl on the regrowth rate of lawns grasses. - Acta Sci. Pol., Hortorum Cultus. 11(4): 67-76

[18] Kitczak, T., Gos, A., Czyż, H., Trzaskoś, M. (2000): Growth and development of grasses and papilionaceous species on ash-slag substance with addition of biohumus and nitrogen fertilisers. - Grassland Science in Poland 3: 71-79. (In Polish).

[19] Martyniak, D., Prończuk, S. (2003): Evaluation of cultivars and strains of chewings and strong creeping sub-species Festuca rubra L. with application of a synthetic index. Bulletin of IHAR Radzików, 225: 303-311. (In Polish).

[20] Prończuk, S., Prończuk, M., Żyłka, D. (1997): Methods of synthetic evaluation of the usable value of lawn grasses. - Advances of Agricultural Sciences Problem Issues 451: 125 - 133. (In Polish)

[21] Prończuk, S., Zurek, D. (2008): The relationship between sod strength and turf quality of common Grass cultivars. - Plant Breed. Seed Sci. 57: 25-34.

[22] Rutkowska, B., Pawluśkiewicz, M. (1996): Lawns. Guidance on setting up and cultivation. - PWRiL Warszawa.

[23] Skowera, B., Puła, J. (2004): Pluviometric extreme conditions in spring season in Poland in the years 1971-2000. - Acta Agrophys. 3(1): 171-177. (In Polish).

[24] Stewart, G. H., Ignatieva M. E., Meurk, C. D., Buckley, H., Horne, B., Braddick, T. (2009): Urban biotopes of aotearoa New Zealand (URBANZ) (I): Composition and diversity of temperate urban lawns in Christchurch. - Urban Ecosystems 12: 233-248.

[25] Watsson, J. R., Kaerwer, H. E., Martin, D. P. (1992): The turfgrass in dustry. - In: Turfgrass. Agron. Monogr. 32: 29-88. 
[26] Wheeler, M. M., Neil, Ch., Groffman, P. M., Avolio, M., Bettez, N., Cavender-Bares, J., Chowdhury, R. R., Darling, L., Grove, J. M., Hall, S. J., Heffernan, J. B., Hobbie, S. E., Larson, K. L., Morse, J. L., Nelson, K. C., Ogden, L. A., O’Neil-Dunne, J., Pataki, D. E., Polsky, C., Steele, M., Trammell, T. L. E. (2017): Continental-scale homogenization of residential lawn plant communities. - Landscape and Urban Planning 165: 54-63. 